\title{
Pembekalan Teknis Pelayanan Online Administrasi Kependudukan Bagi Relawan Milenial Melawan Pandemi Covid 19
}

\author{
Ranggi praharaningtyas Aji ${ }^{1 *}$, Retno Waluyo ${ }^{2}$, Fiby Nur Afiana ${ }^{3}$, Ito Setiawan ${ }^{4}$ \\ 1,2,3,4 Program Studi Sistem Informasi, Universitas Amikom Purwokerto, Indonesia \\ Email: ${ }^{1}$ ranggi@ amikompurwokerto.ac.id, ${ }^{2}$ waluyo@ amikompurwokerto.ac.id, ${ }^{3}$ fiby@ amikompurwokerto.ac.id, \\ 4itosetiawan@amikompurwokerto.ac.id
}

\section{INFORMASI ARTIKEL}

\section{Data artikel:}

Naskah masuk, 17 Juli 2020

Direvisi, 7 Agustus 2020

Diterima, 19 Agustus 2020

\section{Kata Kunci:}

Covid-19

Pelayanan Online

Data Kependudukan

\begin{abstract}
ABSTRAK
Abstract- Coronavirus pandemic in Indonesia has not subsided yet. There are around 100,303 cases suspected to coronavirus during the five months outbreak. In order to deal with the epidemic, volunteers are needed to help media personnel to prevent the transmission of COVID-19 virus. It is done not only by distributing masks or spraying disinfectant but also by preventing the community from gathering at the public administration services. As a millenial volunteer who understands technology, we try to provide an understanding of the public regarding the administration of online documents. The purpose of this activity is to share knowledge to COVID19 volunteers while taking care of population data such an eKTP, birth certificates, and others because it can be done by accessing the DINDUKCAPIL Banyumas website. It is implemented by making presentations and exposure through video conferences via the Cisco Webex Meeting application. The result is the volunteers understand how to handle the population of the online document so that they can share it to their community.
\end{abstract}

Abstrak- Pandemi virus corona di Indonesia belum kunjung mereda. Lima bulan diterpa wabah, kini angka positif virus corona di Indonesia telah menembus 100.303 kasus, untuk menangani pademi tersebut perlu adanya relawan untuk membantu tenaga media mencegah penularan virus COVID-19. Tindakan pencegahan tidak hanya dengan cara membagikan maskeratau melakukan penyemprotan disinfektan saja, namun bias dilakukan dengan cara mencegah masyarakat berkumpul di tempat pelayanan administrasi kependudukan. Sebagai relawan milenial yang memahami teknologi dapat memberikan pemahaman terhadap masyarakat mengenai pengurusan dokumen administrasi secara online. Tujuan kegiatan pengabdian masyarakat ini memberikan pengetahuan pada relawan wabah covid-19 mengurus data kependudukan seperti e-KTP, Akta kelahiran dan lainya karena bisa dilakukan secara online melalui website DINDUKCAPIL Kabupaten Banyumas. Model pelaksanaan kegiatan pengabdian masyarakat dilakukan dengan cara melakukan presentasi dan paparan melalui video conference dengan bantuan aplikasi Cisco Webex Meeting. Hasil yang didapat adalah relawan menjadi paham tentang pengurusan dokumen kependudukan secara online sehingga 
dapat memberikan pemahaman ke masyarakat.

\section{Korespondensi:}

\section{Ranggi Praharaningtyas Aji}

Program Studi Sistem Informasi, Universitas Amikom Purwokerto

Jl.Letjen Pol Sumarto Purwanegara,Purwokerto Utara, Banyumas Indonesia

\section{PENDAHULUAN}

New normal merupakan istilah yang saat ini sedang trend di seluruh dunia. Dimana kita berusaha hidup baru di tengah pandemi Covid19 atau dapat dikatakan berusaha berdamai dengan keadaan melalui beberapa protokol kesehatan yang telah ditetapkan masingmasing daerah (Habibi, 2020). Tidak hanya situasi yang berubah namun perilaku manusia juga harus ikut berubah demi mencegah penularan virus Covid-19. New normal ramai diperbincangkan setelah PSBB (Pembatasan Sosial Berskala Besar) diterapkan beberapa kota di Indonesia seperti DKI Jakarta, Surabaya dan beberapa kota besar lainnya (Muhyiddin, 2020).

Coronavirus disease 2019 atau sering disebut COVID-19 merupakan virus yang pertama kali ditemukan di Wuhan(Di Gennaro et al., 2020)(Setyawan \& Lestari, 2020) dan dapat ditularkan dari manusia ke manusia(Susilo et al., 2020)(Yuliana, 2020). Namun seiring waktu berkembang isu yang mengatakan bahwa virus ini dapat menular melalui udara yang hingga saat ini belum diakui kebenarannya. Virus ini berhasil menyebar di seluruh dunia, dengan 213 negara yang terinveksi. Tak terkecuali di Indonesia, pada tanggal 2 Maret 2020 Presiden Republik Indonesia Joko Widodo bersama dengan Mentri Kesehatan Terawan Agus Putranto mengumumkan kasus Covid-19 pertama di Indonesia (Pakpahan \& Fitriani, 2020). WHO pada tanggal 12 Maret 2020 mengumumkan COVID-19 sebagai sebuah pandemi (World Health Organizatin, 2020).

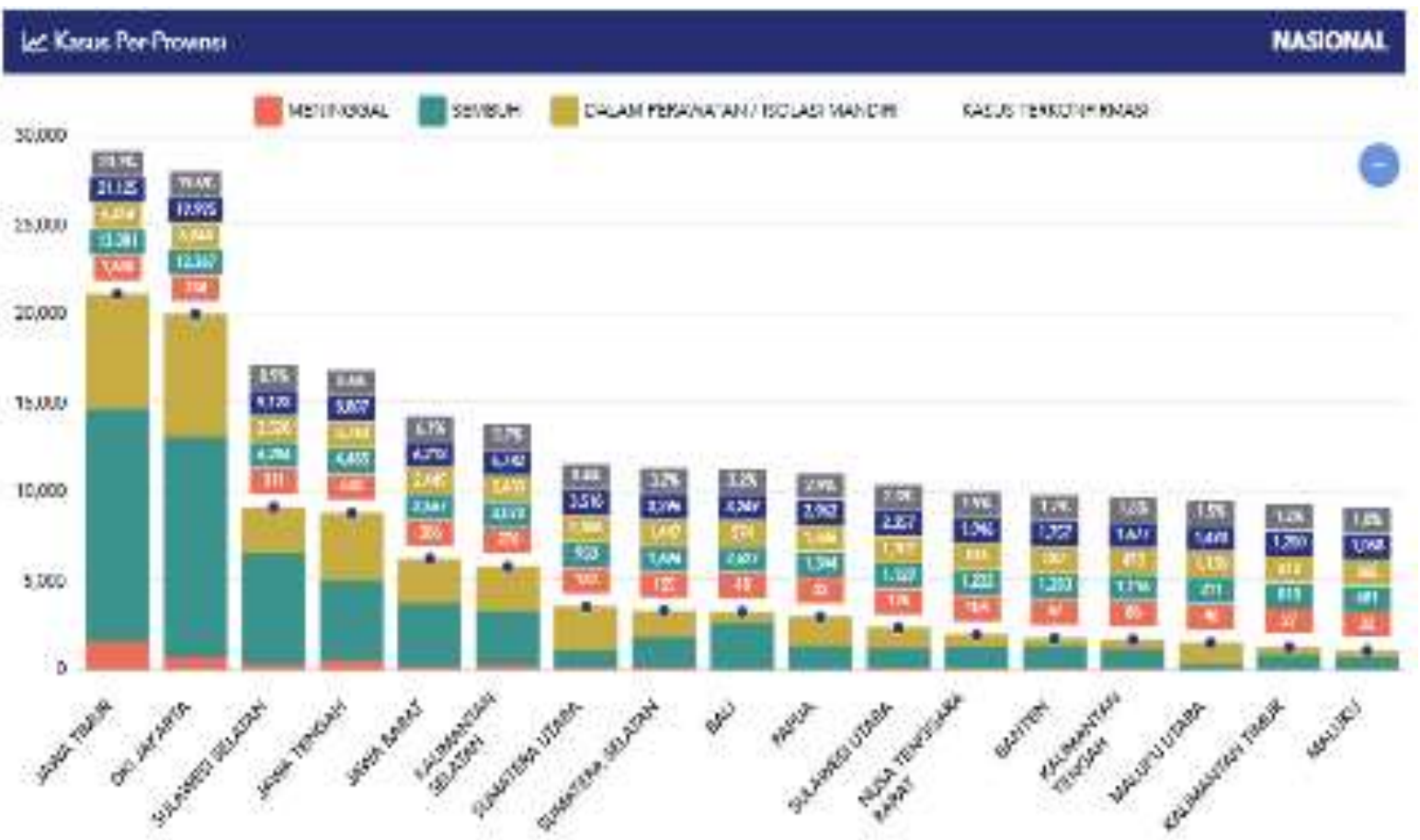

Gambar 1. Data Covid di Indonesia (https://covid19.go.id/)

Gambar diatas menjelaskan bagaimana penyebaran/data pasien di Indonesia berdasarkan propinsi pertanggal 30 Juli 2020, peringkat pertama Jawa Timur diikuti DKI 
Jakarta, Sulawesi Selatan dan propinsi lainya. Hal ini membuktikan masih tingginya angka penyebaran Covid-19.

Berdasarkan pengumuman WHO, Indonesia melalui Juru Bicara untuk penanganan Virus Korona/COVID-19 Achmad Yurianto mengatakan bahwa virus ini dapat menyerang siapa saja dimana saja hingga langkah antisipasi dan kewaspadaan perlu dilakukan (Pakpahan \& Fitriani, 2020). Beribadah dirumah, belajar dirumah dan Work From Home (WFH) merupakan langkah yang diambil pemerintah untuk menekan jumlah pasien positif COVID-19 (Zahrotunnimah, 2020)(Setyawan \& Lestari, 2020). Namun seiring waktu jumlah pasien positif COVID-19 di Indonesia bahkan beberapa negara lainnya terus bertambah tidak mengalami penurunan sedangkan perekonomian harus berjalan untuk menopang kehidupan masyarakat dengan beberapa aturan yang ditetapkan (Telaumbanua, 2020). Beberapa langkah taktis dilakukan pemerintah menuju New Normal, salah satunya dengan bantuan teknologi untuk meringankan manusia dalam menghadapi pandemi COVID-19.

Pengurusan dokumen kependudukan dan lainnya yang selama ini dilakukan dengan mendatangi langsung instansi terkait, sejak pandemi COVID-19 mulai dihentikan. Di era New Normal ini Dinas Kependudukan dan Pencatatan Sipil segala pengurusan dokumen dapat dilakukan secara online melalui beberapa platfrom yang telah disediakan. Hal ini bertujuan untuk tidak menciptakan kerumunan di titik-titik tertentu yang sangat rentan akan penyebaran atau Eli penularan COVID-19. Dalam implementasinya masih banyak masyarakat yang bingung dalam proses pengurusan data kependudukan secara online melalui situs layananonline.dukcapil.kemendagri.go.id dan situs gratiskabeh.banyumaskab.go.id. Sehingga para relawan perlu dibekali kemampuan penggunaan situs tersebut sebelum terjun langsung kemasyarakat. Tujuan kegiatan pengabdian masyarakat ini memberikan pengetahuan pada relawan wabah covid-19 mengurus data kependudukan seperti e-KTP, Akta kelahiran dan lainya karena bisa dilakukan secara online melalui website DINDUKCAPIL Kabupaten Banyumas.

\section{METODE PELAKSANAAN}

Secara menyeluruh konsep kegiatan pelaksanaan pengabdian kepada masyarakat ini dapat dilihat pada gambar 2 .

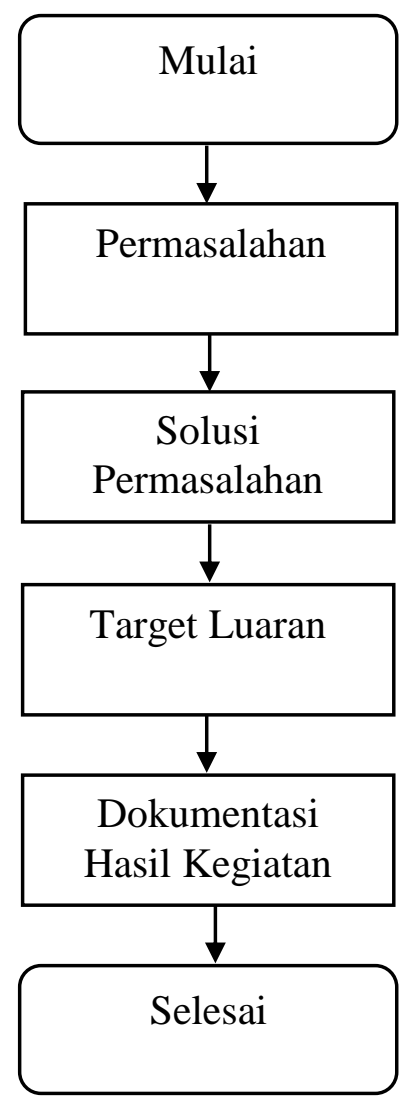

Gambar 2. Konsep Pelaksanaan

Berdasarkan instruksi dari pemerintah untuk tidak menciptakan kerumunan utamanya kerumunan di ruang tertutup untuk menghindari penyebaran COVID-19. Untuk itu pengabdian ini dilaksanakan dengan dengan cara melakukan presentasi dan paparan melalui video conference dengan bantuan aplikasi Cisco Webex Meeting. Metode pengabdian yang digunakan adalah metode pendidikan masyarakat.

Pelaksanaan pengabdian yaitu dengan memberikan pelatihan cara mengurus data kependudukan secara online melalui situs gratiskabeh.banyumaskab.go.id dan layananonline.dukcapil.kemendagri.go.id kepada para relawan COVID 19 Universitas Amikom Purwokerto. Matiri yang akan disampaikan dibagi atas 2(dua) sesi denga $n$ rinci pelaksanaan seperti dijelaskan di bawah: 
a. Sesi 1(satu) Relawan Covid diajarkan cara mengakses dan menggunakan situs gratiskabeh.banyumaskab.go.id.

b. Sesi 2 (dua) Relawan Covid dibekali modul sebagai pedoman cara mengakses situs gratiskabeh.banyumaskab.go.id.

\section{HASIL DAN PEMBAHASAN}

Kegiatan dilaksanakan pada tanggal 20 juni 2020. kegiatan dimulai pukul 09.00 hingga 10.00 dan dilakukan dalam 2 sesi. Peserta yang mengikuti kegiatan pengabdian ini ada 26 relawan covid yang sebagian besar adalah mahasiswa. Selain dari mahasiswa terdapat juga dosen pembimbing relawan yang ikut terlibat menjadi peserta. Data lengkap peserta kegiatan pengabdian ini terlihat pada tabel 1 .

Tabel 1. Data peserta pelatihan

\begin{tabular}{|l|l|l|}
\hline No & Peserta & Jumlah \\
\hline 1 & Mahasiswa & 26 \\
\hline 2 & Dosen pembimbing & 5 \\
\hline
\end{tabular}

Pelaksanaan kegiatan pengabdian ini dilangsungkan dengan bantuan tool

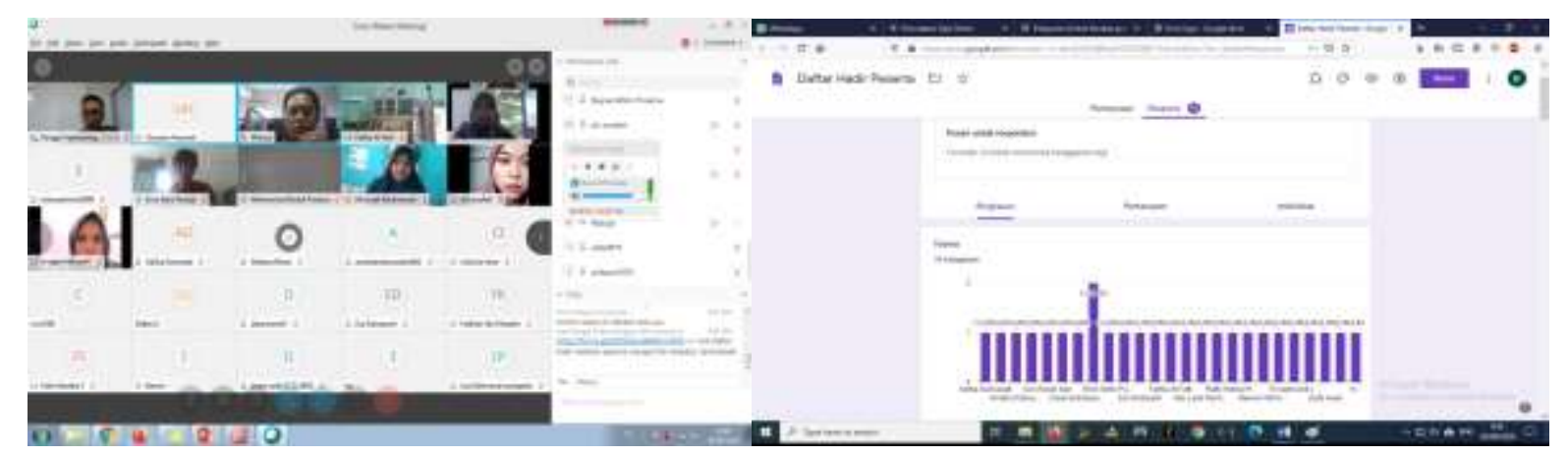

Gambar 3. Peserta Pelatihan

Materi pada pelaksanaan kegiatan pengabdian kepada masyarakat ini dibagi menjadi 2 sesi. Sesi pertama penjelasan cara menggunakan aplikasi dinas kependudukan kabupaten banyumas, dan sesi kedua adalah menggunakan aplikasi milik kementrian dalam negri republik Indonesia.

Materi sesi pertama pada kegiatan ini meliputi :

a. Fungsi dan kegunaan dari situs gratiskabeh.banyumaskab.go.id.

Peserta diarahkan untuk memahami fungsi dari situs gratiskabeh.banyumaskab.go.id. bagi masyarakat. Sehingga dilapangan para peserta dapat menjelaskan kepada masyarakat dengan baik dan dapat diterima oleh masyarakat.

b. Cara penggunaan situs gratiskabeh.banyumaskab.go.id.Hal ini meliputi teknis penggunaan dari gratiskabeh.banyumaskab.go.id. Semua alur cara penggunaan dan juga alat-alat yang dibutuhkan dijelaskan secara menyeluruh. Hal ini bertunjuan untuk membantu peserta dalam memahami teknis dari aplikasi pedulilindungi lebih mudah.

c. Protokol kesehatan selama menjalankan gratiskabeh.banyumaskab.go.id. Pada sesi ini peserta dijelaskan protokol kesehatan yang tetap harus dijalanakan setelah menggunakan situs gratiskabeh.banyumaskab.go.id. Sehingga tidak memunculkan pemahaman yang salah setelah menggunakan apliaksi.

Pada saat penyampaian materi sesi satu juga ditampilkan secara langsung penggunaan situs gratiskabeh.banyumaskab.go.id. Sehingga peserta dapat secara langsung melihat dan memperhatikan tata cara penggunaan yang benar dari situs gratiskabeh.banyumaskab.go.id. Tampilan dari website gratiskabeh.banyumaskab.go.id seperti yang terlihat pada gambar 4 . 


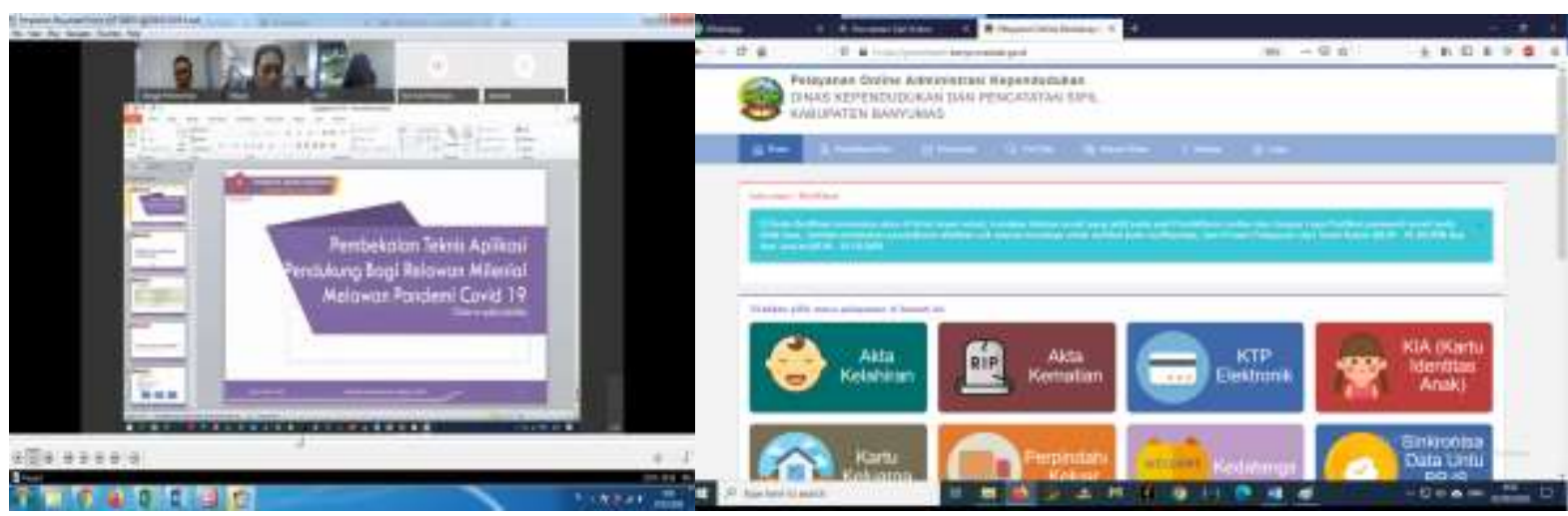

Gambar 4. Pengakses situs dinas kependudukan kabupaten Banyumas

$\begin{array}{cr}\text { Pada sesi } & \text { berikutnya materi } \\ \text { disampaikan } & \text { meliputi }\end{array} \quad \begin{gathered}\text { yang } \\ \text { portal }\end{gathered}$ layananonline.dukcapil.kemendagri.go.id Pada sesi ini disampaikan beberapa hal antara lain :
a. Penjelasan tentang website

layananonline.dukcapil.kemendagri.go.id.

Peserta dijelaskan mengenai pentingnya administrasi data kependudukan dimasa pandemic. Selanjutnya peserta diarahkan untuk menggunakan portal layananonline.dukcapil.kemendagri.go.id dalam melakukan pengadministrasian data kependudukan sehingga masyarakat tidak perlu keluar rumah.

b. Langkah pendaftaran data penduduk dan persyaratan yang diperukan sebelum mengakses portal layananonline.dukcapil.kemendagri.go.id Peserta dibekali pengetahuan mengenai tata cara melakukan administarasi data kependudukan melalui portal layananonline.dukcapil.kemendagri.go.id

Dan menjelaskan kebutuhan yang diperlukan sebelum dan saat melakukan administrasi data kependudukan.

c. Penjelasan tindak lanjut setelah melakukan input data lewat portal layananonline.dukcapil.kemendagri.go.id Selanjutnya peserta juga dibekali dengan informasi mengenai tindak lanjut yang perlu di lakukan setelah melakukan input

Pada saat penyampaian materi sesi dua juga ditampilkan secara langsung penggunaan situs layananonline.dukcapil.kemendagri.go.id. Sehingga peserta dapat secara langsung melihat dan memperhatikan tata cara penggunaan yang benar dari situs gratiskabeh.banyumaskab.go.id. Tampilan dari situs kementrian dalam negeri republik Indonesia seperti yang terlihat pada gambar 5 .

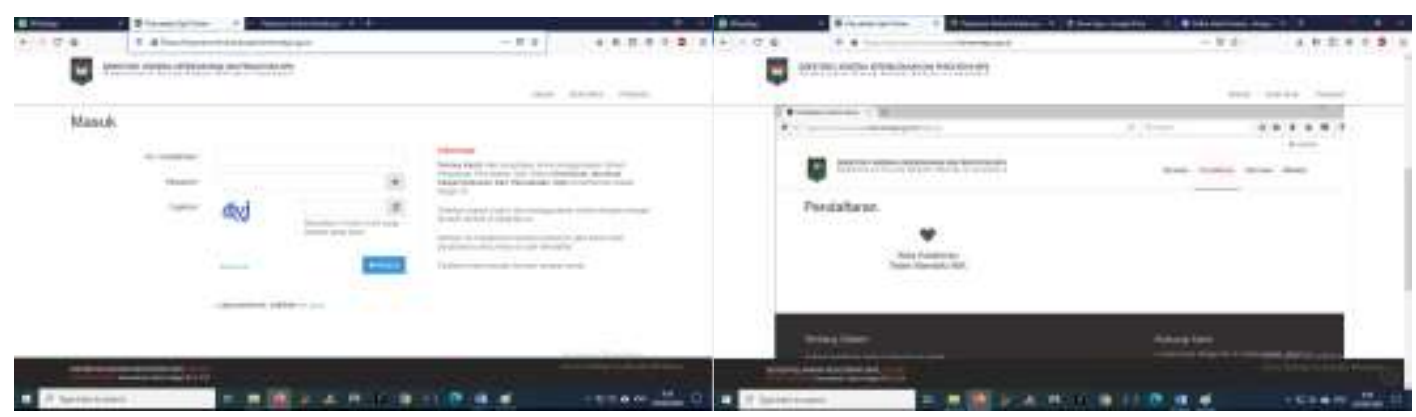

Gambar 5. Pengakses situs kementrian dalam negeri Republik Indonesi.

\section{KESIMPULAN}

Dapat disimpulkan bahwa setelah melakukan pelatihan terhadap para relawan hasilnya adalah relawan menjadi paham tentang pengurusan dokumen kependudukan secara online menggunakan aplikasi yang ada di DINDUKCAPIL Kabupaten Banyumas. 
Sehingga relawan dapat memberikan pemahaman ke masyarakat mengenai pengurusan dokumen kependudukan secara online. Saran bagi pengabdian berikutnya adalah melakukan sosialisasi penggunaan sistem pembayaran pajak kendaraan menggunakan aplikasi SAKPOLE.

\section{UCAPAN TERIMAKASIH}

Termakasih kepada Universitas AMIKOM Purwokerto yang terlah mendukung pelaksanaan dari kegiatan pengabdian masyarakat ini. Dukungan Universitas AMIKOM Purwokerto dalam bentuk Pendanaan AMIKOM Mitra Masyarakat menjadikan kegiatan ini berjalan dengan baik dan lancer. Serta tidak lupa kami mengucapkan terimakasih dan selamat bertugas bagi para relawan COVID-19 Universitas AMIKOM Purwokerto. Semoga para relawan dapat bekerja secara maksimal dan menolong masyarakat dengan lebih baik.

\section{DAFTAR PUSTAKA}

Di Gennaro, F., Pizzol, D., Marotta, C., Antunes, M., Racalbuto, V., Veronese, N., \& Smith, L. (2020). Coronavirus diseases (COVID-19) current status and future perspectives: A narrative review. International Journal of Environmental Research and Public Health, 17(8). https://doi.org/10.3390/ijerph17082690

Habibi, A. (2020). Normal Baru Pasca Covid19. Journal.Uinjkt.Ac.Id, 4(1), 197-202. https://doi.org/10.15408/adalah.v4i1.158 09

Muhyiddin. (2020). Covid-19, New Normal, dan Perencanaan Pembangunan di Indonesia. Jurnal Perencanaan Pembangunan: The Indonesian Journal of Development Planning, 4(2), 240-252. https://doi.org/10.36574/jpp.v4i2.118

Pakpahan, R., \& Fitriani, Y. (2020). Analisa Pemanfaatan Teknologi Informasi Dalam Pembelajaran Jarak Jauh Di Tengah Pandemi Virus Corona Covid-19 Jisamar ( Journal of Information System, Applied , Management, Accounting and Researh ) p-ISSN : 2598-8700 ( Printed ) JISAMAR ( Journal of Inf. JISAMAR, 4(2), 30-36.

Setyawan, F. E. B., \& Lestari, R. (2020).
Challenges of Stay-At-Home Policy Implementation During the Coronavirus (Covid-19) Pandemic in Indonesia. Jurnal Administrasi Kesehatan Indonesia, $\quad 8(2), \quad 15$. https://doi.org/10.20473/jaki.v8i2.2020.1 5-20

Susilo, A., Rumende, C. M., Pitoyo, C. W., Santoso, W. D., Yulianti, M., Herikurniawan, H., Sinto, R., Singh, G., Nainggolan, L., Nelwan, E. J., Chen, L. K., Widhani, A., Wijaya, E., Wicaksana, B., Maksum, M., Annisa, F., Jasirwan, C. O. M., \& Yunihastuti, E. (2020). Coronavirus Disease 2019: Tinjauan Literatur Terkini. Jurnal Penyakit Dalam Indonesia, $\quad 7(1), \quad 45$. https://doi.org/10.7454/jpdi.v7i1.415

Telaumbanua, D. (2020). Urgensi Pembentukan Aturan Terkait Pencegahan Covid-19 di Indonesia. QALAMUNA: Jurnal Pendidikan, Sosial, Dan Agama, 12(01), 59-70. https://doi.org/10.37680/qalamuna.v12i0 1.290

World Health Organizatin. (2020). WHO Director-General's opening remarks at the media briefig on COVID-19 - 11 March 2020. Who.Int. https://www.who.int/dg/speeches/detail/ who-director-general-s-opening-remarksat-the-media-briefing-on-covid-19---11march-2020

Yuliana. (2020). Corona virus diseases (Covid -19); Sebuah tinjauan literatur. Wellness and Healthy Magazine, 2(1), 187-192. https://wellness.journalpress.id/wellness/ article/view/v1i218wh

Zahrotunnimah, Z. (2020). Langkah Taktis Pemerintah Daerah Dalam Pencegahan Penyebaran Virus Corona Covid-19 di Indonesia. SALAM: Jurnal Sosial Dan Budaya Syar-I, 7(3). https://doi.org/10.15408/sjsbs.v7i3.15103 